American Journal of Applied Sciences 9 (5): 673-677, 2012

ISSN 1546-9239

(C) 2012 Science Publications

\title{
Comparative Study on Sustainable Agriculture Knowledge among Malaysian Contract Farmers
}

\author{
Azmariana Azman, Jeffrey Lawrence D'Silva, \\ Bahaman Abu Samah, Norsida Man and Hayrol Azril Mohamed Shaffril \\ Laboratory of Sustainable Development and Agriculture Extension, \\ Institute for Social Science Studies, Universiti Putra Malaysia, Malaysia
}

\begin{abstract}
Problem statement: Modern farming methods like contract farming must emphasize on the need to practice sustainable agriculture so that it will lead towards the development of the agriculture sector. To do so, knowledge is paramount as this will enable the implementation of good agriculture practices. What is the current level of knowledge of contract farmers with regards to sustainable agriculture? Is there any difference in the level of knowledge between farmers from different zones? Thus, this study would like to investigate on the level of knowledge pertaining to sustainable agriculture practices between contract farmers from east and west Malaysian. Approach: This study used a survey methodology to obtain the data. A total of 160 respondents participated in the study and the data was analyzed using the SPSS software. Results: From the result, it was identified that the respondents were at a high level pertaining to their knowledge on sustainable agriculture. Further analysis showed that there is a significant difference in knowledge based on different zones. Conclusion: The study recommends that more efforts should be taken by respective stakeholders to further improve farmers' knowledge regarding pest control, soil erosion and proper usage of machine for agriculture.
\end{abstract}

Key words: Sustainable agriculture, contract farmers, knowledge, Malaysia

\section{INTRODUCTION}

People all around the world depend immensely on agriculture as one of the main sources to fulfill their basic needs and doubtlessly agriculture is pertinent for the survival of mankind. In Malaysia, agriculture has been identified as an important avenue to strengthen the national Gross Domestic Products (GDP) and thus far had created job opportunities for $16 \%$ of the population. Besides, the Agriculture National Key Economic Area (NKEA) targets to increase the agriculture sector's Gross National Income (GNI) contribution to RM49.1 billion by 2010, through 16 Entry Point Projects (EPPs) and 11 business opportunities. The Agriculture NKEA targets the creation of 74,000 job opportunities and to increase the income of farmers by 2-4 times higher.

The above data signifies the Government's strategies to strengthen the agriculture sector and in the process to improve farmers' quality of life. In order to achieve the economic target, two other important elements that should not be neglected are the social wellbeing and environment soundness. One of the ways to achieve equilibrium in the three components of economic, social well-being and environment friendly is through practicing sustainable agriculture among farmers so that it will help them to increase their productivity as well as to achieve stability in the three dimensions of social well-being, economic and the environment.

Sustainable agriculture is often cited to encompass of three main goals namely economic efficiency, environmental quality and social responsibility (D'Silva et al., 2011a). Despite the diversity in conceptualizing sustainable agriculture, there is a mutual agreement on the keys for sustainable agriculture successes namely (i) maintenance of environmental quality, (ii) economically justifiable through stable plant and animal productivity, and (iii) socially desirable (Sharghi et al., 2010). Even though a sustainable farm must possess both economic and environmental successes nonetheless it must not leave behind the role of social capital (such as family quality of life, human health, relationships based on family and community) (Asadi et al., 2008). Previously, efforts to develop the agricultural sector depended heavily on conventional ways to produce, increase and sustain food production. The usage of chemical fertilizers was much needed by

Corresponding Author: Jeffrey Lawrence D’Silva, Laboratory of Sustainable Development and Agriculture Extension, Institute for Social Science Studies, University Putra Malaysia, Malaysia 
that time in order to supply plant nutrients and chemicals to combat pest and diseases. However, in recent years, as a result of increasing awareness on health and environment issues, systematic programs have been introduced to optimize the use of resources on a sustainable basis including the recycling of waste products for food production and environment protection, and an increasing commitment to reduce relaince on excessive chemical inputs in agriculture (Liaghat and Balasundram, 2010). Sustainability is the way to provide more healthy foods in the future considering the increasing population and growing demand of agricultural products (Sharghi et al., 2010). Also, sustainable agriculture has been seen as contributor to generate more economic and quality life to the farmers. In a way to make it become reality, the group that is mainly responsible to carry out sustainability in agriculture is the farmers.

Of late, much emphasis is given to generate farmers that venture into modern and innovative farming methods and one of them is contract farming (D'Silva et al., 2011b). Contract farming is the vertical coordination between growers of an agricultural product and buyers or processors of that product. Contract farming also can be defined as agricultural production carried out according to a prior agreement in which the farmer commits to producing a given product in a given manner and the buyer commits to purchasing it. Often, the buyer provides the farmer with technical assistance, seeds, fertilizer and other inputs on credit and offers a guaranteed price for the output (PinstrupAndersen and Cheng, 2009). Contracts may provide production inputs, credit and extension services to the grower in return for market obligations on such considerations as the methods of production, the quantity that must be delivered and the quality of the product (Warning and Hoo, 2000). The report by Sartorius and Kirsten (2006) on the potential benefits of contract farming for the small black farmers in South Africa described the benefits as "a potential 'win-win' situation for government, agribusiness and the agricultural input manufacturers". In fact the benefits are more far reaching than the one suggested above. The prime advantage of a contractual agreement for farmers is that the sponsor will normally undertake to purchase all produce grown, within specified quality and quantity parameters. Contracts can also provide farmers with access to a wide range of managerial, technical and extension services that otherwise may be unobtainable (Man and Nolila, 2010). From the above, it is clear that contract farming actually gives much benefit to both parties-contract farmers and the buyers of the agricultural products.
It cannot be denied that contract farmers too need to implement and practice sustainable agriculture. To ensure farmers do practice sustainable agriculture, one of the important components is farmers should have adequate knowledge pertaining to sustainable agriculture.

Internal and external knowledge are key components in improving small-scale agricultural production and linking increased production to remunerative markets, thus leading to improved rural livelihoods, improving quality and yield, food security and national economies (Asaba et al., 2006). Without adequate knowledge, contract farmers cannot implement good agriculture practices in their cultivation the crops

In the Malaysian context, it is often mentioned that there is a disparity in farming practices (such as traditional versus modern methods) and level of knowledge regarding farming between the various groups of the farming community in both east and west Malaysia. However, not many studies were carried out to determine the level of knowledge specifically on sustainable agriculture among various farmers in Malaysia. Thus, this study is designed to investigate on whether discrepancy in knowledge pertaining to sustainable agriculture practices does exists between contract farmers from east and west Malaysian.

\section{MATERIALS AND METHODS}

The study employed a survey research methodology to gather information pertaining to knowledge of contract farmers about sustainable agricultural practices. To acquire the items for the instrument, a search was done on previous studies to obtain the relevant information and these items after being identified were later validated by a panel of agriculture researchers to ensure its content validity. Eventually, a total of 14 questions related to sustainable agriculture knowledge were prepared for the respondents. For each of the questions, the respondents were given a five likert-type scale of answer ranging from 1 (strongly agree) to 5 (strongly disagree).

Simple random sampling was employed in this study. The list of contract farmers was obtained from two government agencies and they are Federal Agriculture Marketing Authority (FAMA) and Rural Development Co-operative, Sabah. A total of 160 respondents were involved in this study and the selected respondents were involved in a number of crop activities in east and west Malaysia.

Prior to the actual study, a pre-test was conducted and the overall Cronbach alpha obtained 
was above the threshold of 0.7 , indicating that the items were reliably sound.

To ease the data collection process, assistance from the Federal Agriculture Marketing Authority officers were requested. The data collection process was carried out by trained enumerators where the average time taken by the enumerators to complete each respondent was 25 $\min$. The data collection was conducted at two states, one in Kedah that represented the west Malaysia and the other in Sabah that represented the east Malaysia.

SPSS was used in the data analysis process. Both descriptive and inferential statistics were employed to describe the data and also to explain on whether there is a significant difference in the construct of knowledge based on the two zones studied. An exploratory data analysis was conducted to check on outliers and to ensure that the distribution of the data was normal and the fulfilment of the assumption of homogeneity of variance.

\section{RESULTS}

Respondents background: The socio-demographic characteristics of the respondents of this study are shown in Table 1. In terms of age, a total of $26.9 \%$ of the respondents were in the age group of 51-60 years and followed by age group ranging between 41-50 years which is $25.0 \%$. The mean age of the respondents was 46.22 years old. On the other hand, in terms of gender, there are more males working as contract farmers compared to females and it is not surprising as a number of previous studies have proven that there are more male workers in the agriculture sector compared to females (Shaffril et al., 2010). In terms of level of education, $31.2 \%$ of them do not have any formal education while a total of $43.1 \%$ of contract farmers in west and east Malaysia possessed primary school level of education. Only a minority of the respondents $(0.6 \%)$ possessed diploma level of education. Based on Table 1 , there was an equal distribution in terms of race where each of the race, Malay and Dusun were represented by $50 \%$ of the respondents. Regarding years of experience, more than half of respondents $(68.1 \%)$ have less than 10 years' experience in contract farming. The mean score for year of experience was 9.95. Besides, the data also showed $76.2 \%$ of the respondents earned less than RM1000 per month.

Level of knowledge towards sustainable agriculture: Table 2 demonstrates finding related to the main objective of this paper, that is, to identify the level of knowledge of the contract farmers in Malaysia towards sustainable agriculture. Table 2 reveals that nearly three quarters of the respondents $(71.2 \%)$ have high level knowledge of sustainable agriculture. It can be noted that $26.2 \%$ have moderate knowledge about sustainable agriculture and only $2.5 \%$ of the respondents still have low knowledge towards sustainable agriculture.

Mean score on items of knowledge of sustainable agriculture: As being mentioned earlier, a fourteenitem instrument was used to measure the respondents' knowledge on sustainable agriculture (Table 3). The three highest mean score were recorded by the statement of "the importance to preserve water/soil because it is limited resources" ( $M=4.58)$, followed by "the total number of seeds that are appropriate to the size of cultivated land" $(\mathrm{M}=4.54)$ and about "the importance of utilizing organic compost" $(\mathrm{M}=4.45)$.

Apart from this, the lowest mean score was recorded by the statement of "crop weeds is essential to eradicate pests" $(\mathrm{M}=3.48)$. This depicts that all the concerned parties in agriculture such as extension agents, NGOs, government and should provide farmers with the necessity exposure and assist them to gain more knowledge and information related to the crop weeds as a source to eradicate pests.

\begin{tabular}{|c|c|c|c|c|}
\hline Respondent's profile & & $\mathrm{n}$ & $(\%)$ & Average \\
\hline \multirow[t]{6}{*}{$\overline{\text { Age }}$} & $<30$ years & 22 & $(13.8)$ & 46.22 \\
\hline & $31-40$ years & 33 & (20.6) & \\
\hline & $41-50$ years & 40 & $(25.0)$ & \\
\hline & $51-60$ years & 43 & (26.9) & \\
\hline & $61-70$ years & 17 & (10.6) & \\
\hline & $>70$ years & 5 & $(3.1)$ & \\
\hline \multirow[t]{2}{*}{ Sex } & Male & 110 & $(68.8)$ & \\
\hline & Female & 50 & $(31.2)$ & \\
\hline \multirow[t]{6}{*}{ Education level } & No Formal Education & 50 & $(31.2)$ & \\
\hline & Primary School & 69 & $(43.1)$ & \\
\hline & PMR/SRP & 8 & $(5.0)$ & \\
\hline & SPM/SPMV/MCE & 27 & $(16.9)$ & \\
\hline & Skills Certificate/STPM & 15 & $(3.1)$ & \\
\hline & Diploma & 1 & $(0.6)$ & \\
\hline \multirow[t]{4}{*}{ Ethnic } & Malay & 80 & $(50.0)$ & \\
\hline & Chinese & 0 & $(0.0)$ & \\
\hline & India & 0 & $(0.0)$ & \\
\hline & Others & 80 & $(50.0)$ & \\
\hline \multirow{3}{*}{$\begin{array}{l}\text { Number of years of } \\
\text { experience }<10 \text { years }\end{array}$} & 109 & $(68.1)$ & 9.95 & \\
\hline & $11-20$ years & 34 & $(21.2)$ & \\
\hline & $>21$ years & 17 & (10.6) & \\
\hline \multirow[t]{4}{*}{ Monthly income } & $<\mathrm{RM} 1000$ & 122 & $(76.2)$ & 1411.44 \\
\hline & RM1001-RM 5000 & 28 & (17.5) & \\
\hline & RM5001-RM 10,000 & 7 & $(4.4)$ & \\
\hline & $>\mathrm{RM} 10,001$ & 3 & $(1.90$ & \\
\hline
\end{tabular}

Table 2: Overall level of knowledge toward sustainable agriculture

\begin{tabular}{lllll}
\hline Level & $\mathrm{n}$ & $(\%)$ & Mean & S.D \\
\hline Low (1.00-2.33) & 4 & $(2.5)$ & 4.072 & 0.775 \\
Moderate (2.34-3.67) & 42 & $(26.2)$ & & \\
High (3.68-5.00) & 114 & $(71.2)$ & & \\
\hline
\end{tabular}


Am. J. Applied Sci., 9 (5): 673-677, 2012

Table 3: Level of knowledge on sustainable agriculture among contract farmers

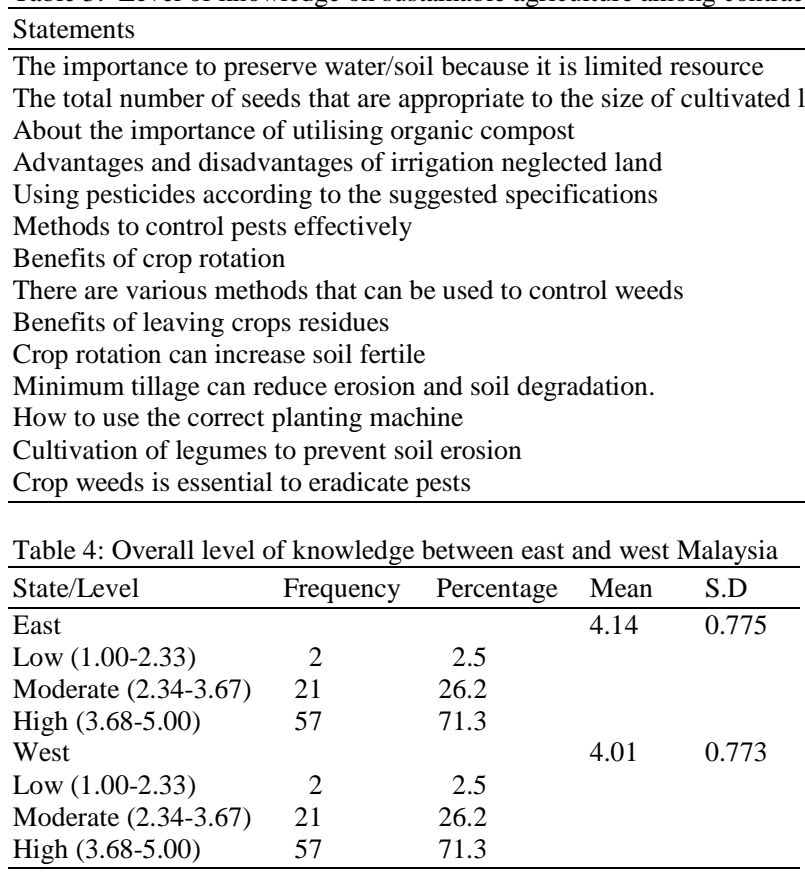

Table 5: Comparison level of knowledge between east and west Malaysia

\begin{tabular}{llllll}
\hline Zone & $\mathrm{n}$ & Mean & $\mathrm{SD}$ & $\mathrm{t}$ & $\mathrm{p}$ \\
\hline East & 80 & 4.14 & 0.775 & 2.494 & 0.014 \\
West & 80 & 4.01 & 0.773 & & \\
\hline
\end{tabular}

Level of knowledge between east and west Malaysia: Next, is the information regarding the level of knowledge on sustainable agriculture practices between contract farmers in east and west Malaysia. From Table 4 , both west and east Malaysia had similar level of knowledge which is $71.3 \%$ for high level, $26.2 \%$ (moderate level) and low level the data showed 2.5\%. However, based on the mean score, it showed that the mean scores for the contract farmers in east Malaysia $(\mathrm{M}=4.14, \mathrm{SD}=0.775)$ is higher compared to the contract farmers in west Malaysia $(\mathrm{M}=4.01, \mathrm{SD}=$ 0.773 ) in terms of knowledge pertaining to sustainable agriculture practices.

Differences on level of knowledge based on zones: An independent t-test was carried out to determine whether there exists any significant difference on the level of knowledge based on the two zones. As in Table 5 , the finding showed that since the $\mathrm{p}$ value is equivalent to 0.014 that is less than the alpha value of 0.05 , thus the null hypothesis is rejected and the conclusion is that there is a significant difference in the level of knowledge between contract farmers in east and west Malaysia.

\begin{tabular}{ccrlll}
\multicolumn{1}{c}{1} & \multicolumn{1}{c}{2} & \multicolumn{1}{c}{3} & 4 & 5 & Mean \\
- & 0.6 & 1.9 & 36.9 & 60.6 & 4.58 \\
- & - & 3.8 & 38.1 & 58.1 & 4.54 \\
0.6 & 1.9 & 6.2 & 34.4 & 56.9 & 4.45 \\
1.2 & 1.2 & 5.0 & 41.2 & 51.2 & 4.40 \\
- & 4.4 & 5.6 & 36.2 & 53.8 & 4.39 \\
- & 3.1 & 8.8 & 37.5 & 50.6 & 4.36 \\
2.5 & 2.5 & 5.0 & 36.2 & 53.8 & 4.36 \\
0.6 & 1.9 & 11.9 & 35.6 & 50.0 & 4.32 \\
2.5 & 1.2 & 8.8 & 38.1 & 49.4 & 4.31 \\
1.9 & 4.4 & 4.4 & 41.2 & 48.1 & 4.29 \\
0.6 & 6.2 & 7.5 & 46.9 & 38.8 & 4.17 \\
6.2 & 6.2 & 12.5 & 33.8 & 41.2 & 3.98 \\
4.4 & 26.9 & 5.6 & 38.8 & 24.4 & 3.52 \\
10.6 & 18.1 & 11.2 & 33.1 & 26.9 & 3.48 \\
\hline
\end{tabular}

\section{DISCUSSION}

From the above findings, it is noted that there is a significant difference in terms of knowledge towards sustainable agriculture between the two groups studied. The contract farmers from east Malaysia were identified to have a better knowledge towards sustainable agriculture compared to their counterparts in west Malaysia. One of the reasons that might contribute to this scenario is that the east Malaysian contract farmers are well-known with their traditional ways of agriculture, since most of them inherit their methods and styles of farming from their parents. Consequently they are practicing natural and organic agriculture; free from chemical and pesticides. It is undeniable that farmers who are more attached with the nature are poised to be more environment-friendly, knowledgeable about their own situations, their resources, what works and what does not work and how one thing can have significant impacts on the other parts in the ecosystem (Traikova et al., 2007). Furthermore according to Traikova et al. (2007), farmers can gain much agriculture knowledge through their interactions with elderly, parents, grandparents, relatives and friends. In the current scenario, this could be the reason that could influence the farmers from the east Malaysia to possess good agriculture practices. It is evident that even though contract farmers in the east Malaysia are exposed with modernization and being provided with all sorts of agriculture facilities, they still depend on what have been practiced years before by their parents and grandparents that have naturally farmed according to good agriculture practices.

\section{CONCLUSION}

Based on the gained results, it is evident that despite both the east and west Malaysia contract farmers are having adequate knowledge regarding sustainable agriculture, there is still much that need to 
be done to further enhance their level of knowledge especially with regards to eradication of pests, soil erosion and proper usage of machinery. It is believed that such impartation of knowledge can only be materialized if there is enough support from every stakeholder-right from the policy makers to the farmers. Thus, it is recommended that all relevant parties will play their roles accordingly so that the objective of each farmer implementing good agriculture practices will be materialized so that our future generations will have sufficient soil to do farming.

\section{REFERENCES}

Asaba, J.F., R. Musebe, M. Kimani, R. Day and M. Nkonu et al., 2006. Bridging the information and knowledge gap between urban and rural communities through rural knowledge centres: Case studies from kenya and uganda. Q. Bull. Int. Assoc. Agric. Inform. Specialists, 51: 143-151.

Asadi, A., M. Akbari, H.S. Fami and H. Iravani, 2008. Poverty alleviation and sustainable development: The role of social capital. J. Soc. Sc., 4:202-215. DOI: $10.3844 /$ jssp.2008.202.215

D'Silva, J.L., B.A. Samah, J. Uli and H.A.M. Shaffril, 2011a. Towards developing a framework on acceptance of sustainable agriculture among contract farming entrepreneurs. Afr. J. Bus. Manage., 5: 8110-8116.

D'Silva, J.L., N. Man, H.A.M. Shaffril and B.A. Samah, 2011b. Acceptance of sustainability agricultural practices: The case of crop farmers. Am. J. Agric. Biol. Sci., 6: 227-230. DOI: 10.3844/ajabssp.2011.227.230

Liaghat, S and S.K. Balasundram, 2010. A review: The role of remote sensing in precision agriculture. Am. J. Agric. Biol. Sci., 5:50-55. DOI: 10.3844/ajabssp.2010.50.55
Man, N. and M.N. Nolila, 2010. The practices of contract farming among fresh fruit and vegetable suppliers in Malaysia. Am. J. Agric. Biol. Sci., 5: 321-330. DOI: 10.3844/ajabssp.2010.321.330

Pinstrup-Andersen, P. and F. Cheng, 2009. Case Studies in Food Policy for Developing Countries: Institutions and International Trade Policies. 1st Edn., Cornell University Press, Ithaca, New York, ISBN: 0801475562, pp: 256.

Sartorius, K. and J. Kirsten, 2006. Contracts and contract farming as potential mechanisms to improve market access for black farmers in South Africa. University of the Witwatersrand.

Shaffril, H.A.M., J.L. D'Silva, J. Uli and B.A. Samah, 2010. Gender issue in contract farming: The case of Malaysian students. Am. J. Agric. Bio. Sc., 5: 204-209. DOI: 10.3844/ajabssp.2010.204.209

Sharghi, T., H. Sedighi and A.R. Eftekhari, 2010. Effective factors in achieving sustainable agriculture. Am. J. Agric. Bio. Sc., 5:235-241. DOI: 10.3844 ajabssp.2010.235.241

Traikova, D., J. Mollers, J. Fritzsch and G. Buchenrieder, 2007. Some conceptional thoughts on the impact of social networks on non-farm rural employment. Leibniz Institute of Agricultural Development in Central and Eastern Europe (IAMO), Germany.

Warning, M. and W.S. Hoo, 2000. The impact of contract farming on income distribution: Theory and evidence. Proceedings of the Western Economics Association International Annual Meetings, Jun. 30, pp: 1-25. 